\title{
The Paradox of Fear in Classical Indian Buddhism ${ }^{\mathrm{I}}$
}

\author{
Bronwyn Finnigan \\ Australian National University
}

\begin{abstract}
The Nikāya Suttas frequently mention the concept of fear (bhaya) and related synonyms. This concept does not receive much scholarly attention by subsequent Buddhist philosophers. Recent scholars identify a 'paradox of fear' in several traditions of classical Indian Buddhism (Brekke 1999, Finnigan 2019, Giustarini 2012). Each scholar points out, in their respective textual contexts, that fear is evaluated in two ways; one positive and the other negative. Brekke calls this the "double role" of fear (1999: 443). Each also identify fear as purposely elicited to motivate acts aimed at achieving fearlessness, where freedom from fear is characteristic of nibbāna. They all find this puzzling. Finnigan asks: "Why would one purposefully incite fear if one's goal is its elimination?" (2019: 22I). Giustarini says that fear has a "contradictory nature" (2012: 513); Brekke calls it "the paradox of fear" (I999: 442). This article introduces the 'paradox of fear' as it appears in the Bodhicaryāvatāra of Sāntideva and the Nikāya suttas. It then critically examines Brekke and Giustarini's proposed solutions. It argues that they get some things right in ways that are both supported by the Nikāyas and relevant to Sāntideva but that they leave some important questions unanswered. The article contends that these questions are best answered if fear is analysed as appropriate when its objects are related to karma and rebirth.
\end{abstract}

The early teachings of the Buddha, as recorded in the Nikāya suttas of the Pāli canon, frequently mention the concept of fear (bhaya, P., Skt.) and related synonyms. They also treat fearlessness as a characteristic of the goal of Buddhist practice, the achievement of nibbāna (P. nirvāna, Skt.). The concept of fear does not receive much scholarly attention by subsequent Buddhist philosophers, however. The Abhidhamma (P., Abhidharma, Skt.) tradition that emerged in the centuries after the Buddha's death sought to systematise the

\footnotetext{
${ }^{\mathrm{I}}$ Many thanks to Felmon Davis and the helpful suggestions of an anonymous reviewer.
} 
Buddha's teachings into a complete and exhaustive theory of the mind and reality, with a special focus on his psychological claims. But the main texts in this tradition barely mention fear. This is surprising.

Some recent scholars critically examine Buddhist views on fear. Giuliano Giustarini (2012) examines remarks about fear found in the Nikāya suttas and Theravāda Abhidhamma commentaries. Torkel Brekke (1999) also considers the Vinaya Pitaka, the Milindapañha, and some Mahāyāna sūtras. ${ }^{2}$ Bronwyn Finnigan (2019) analyses remarks made by Śāntideva in his Bodhicaryāvatāra. Despite these diverse textual contexts, these scholars identify the same puzzle in the Buddhist use and evaluation of fear. Each scholar notes that fear is evaluated in two ways; one positive and the other negative. Brekke calls this the "double role" of fear (I999: 443). Each also recognise that fear is purposely elicited or recommended to motivate acts aimed at achieving fearlessness, where freedom from fear is characteristic of nibbāna. They all find this puzzling. Finnigan asks: "Why would one purposefully incite fear if one's goal is its elimination? In logical terms, why generate $p$ if the goal is $\sim p$ ?" (2019: 22I). Giustarini says that fear has a "contradictory nature" (2012: 513); Brekke calls it "the paradox of fear" (I999: 442). While, strictly speaking, I don't think there is a logical paradox here, I agree that there is something puzzling about the way Buddhists talk about and use fear that needs explaining.

This article begins by introducing the 'paradox of fear' (stated in inverted commas) as it appears in the Bodhicaryāvatāra of Śāntideva (I) and the Nikāya suttas (2), with some reference to the commentaries of Buddhaghoṣa. It then critically examines Brekke and Giustarini's proposed solutions (3). It argues that they get some things right in ways that are both supported by the Nikāyas and relevant to Sāntideva but that they leave some important

\footnotetext{
${ }^{2}$ Brekke also contextualises Buddhist views on fear in the history of Indian religious thought, reminding us that "fear is a vast subject in Indian literature" (I999: 440) and that "there are clear parallels" between Buddhism, Jainism and Hinduism in viewing "freedom from fear as a characteristic of the goal of religious striving" (446). Brekke also argues that "the same paradox of fear can be found in Jainism" (443) but thinks that Buddhism is distinctive in its use of "fear as a means to religious striving" (454).
} 
questions unanswered. The article concludes by arguing that these questions are best answered if fear is analysed as appropriate when its objects are related to karma and rebirth (4).

\section{Sāntideva on fear and taking refuge}

In Chapters 2 \& 7 of the Bodhicaryāvatāra (BCA), Sāntideva makes a series of provocative remarks aimed at inciting fear in his audience to motivate them to 'take refuge' in the Bodhisattvas ("the mighty Protectors of the world" BCA 2.48). He also identifies fearlessness as the goal of this practice. He writes: ${ }^{3}$

Night and day, without respite, more life is lost. It never gets longer. Surely, will I not die? (2.40)

Though here laid on my bed, though in the midst of family, it is alone that I must endure the agony of the throes of death. (2.4I)

Even someone taken away today to have a limb cut off writhes, throat parched, gaze wretched. He sees the world in a completely different way. (2.44)

But that is nothing to the feverish horror which grips me, covered in my own uncontrolled excrement, as Death's terrifying messengers stand over me (2.45)

When Death is sizing you up and at every turn the way is blocked, how can it please you to eat? How can you sleep? How make love? (7.6)

Realizing you are like a captive fish, how right it is for you to be afraid right now? How much more so when you have committed evil action and are faced with the intense agonies of hell? (7.II)

With cowering glances, I search the four directions for deliverance. What saint will deliver me from this great fear? (2.46)

Right now, I go for refuge to the mighty Protectors of the world, who have undertaken the care of the world, the Conquerors who remove all fear (2.48)

Trembling with fear I give myself to Samantabhadra and again, freely I give myself to Mañjughoṣa (2.50)

I have transgressed your command. Now, at seeing the danger, terrified, I go to you for refuge. Destroy the danger quickly (2.54)

I give myself wholly to the Conquerors and to their sons... You take possession of me. I become fearless (2.8-9)

\footnotetext{
${ }^{3}$ I am here copying the verses cited in Finnigan (2019). It is not a continuous passage, but a series of verses
} selected and ordered for the purposes of discussion. 
These verses are not only vividly poetic but also philosophically intriguing as they appear to assume competing attitudes to fear. On the one hand, Sāntideva explicitly endorses fear as appropriate ("how right it is for you to be afraid right now" 7.II) and the graphic content in these verses seems positively aimed at inciting fear in his audience. The ostensive purpose for this is to motivate a certain response to the object of fear which, in the context of these verses, is the karmic suffering anticipated to follow death. And the specific response Sāntideva seeks to motivate is that of "taking refuge" (śaraṇaṃ, Skt.) in the "assembly of Bodhisattvas" (2.49). In apparent contrast to this positively endorsed and utilized sense of fear, Sāntideva goes on to describe the outcome of taking refuge as having "become fearless" (2.9). This is puzzling since it implies that fear is (also) a negative mental state to be removed. If fear is a negative mental state to be removed, why incite it in the first place? If it has positive motivational force, why would we need deliverance from it?

Before discussing this further, two technical ideas need to be explained: karmic suffering and the bodhisattva. What I am calling 'karmic suffering' is the suffering anticipated to be experienced in the next life after death as "the inevitable result of wrong" (2.63). It assumes the concept of rebirth or cyclic existence (samsāra Skt. P.) as well as the laws of karma (Skt.). Sāntideva, like the Buddha and most scholars in classical India, accepted a cosmology of multiple realms or modes of existence into which sentient beings are reborn in a continuous cycle, each defined in terms of their distinct modes of suffering. Where one is reborn is driven by the law of karma which operates over moral action; good actions generate karmic merit, bad actions generate karmic demerit. An agent's accumulated karmic debt determines their next mode of existence, and it causes some auspicious and inauspicious events to occur in that life. ${ }^{4}$ It also partially explains the nature and fact of their present existence as well as some of the auspicious and inauspicious events

\footnotetext{
${ }^{4}$ I say 'some' because Buddhism recognises other forms of causation and does not explain all possible happenings in terms of karmic causation.
} 
that occur in that life. While each realm or mode of existence is impermanent, some (such as the heavenly and hell realms) are said to last for extreme lengths of time (SNI.6.I.I, Braarvig 2009). Being reborn as human is conceived as the best destination because it affords the opportunity to learn and practice the Buddha's teachings and thereby end the cycle of rebirth (Harvey 2000).

Sāntideva is a Mahāyāna Buddhist. Mahāyāna Buddhism distinctively recognizes certain texts as authoritative recordings of the Buddha's teaching in addition to those contained in the Pāli canon. The concept of a bodhisattva is central to this tradition of Buddhism. A bodhisattva is someone who has committed themselves to forego personal liberation from cyclic existence and to be continuously reborn for the purpose of relieving the suffering of all sentient beings. This commitment is said to be motivated by their great compassion for the suffering of others, and its expression in action is informed by moral virtues or perfections. Not only is the bodhisattva thought to be an ideal to which one should aspire, it is an ideal that many Mahāyāna Buddhists think is instantiated by a community of divine beings; the "assembly of Bodhisattvas" (2.49).

In the above verses, Sāntideva seems to elicit fear of karmic suffering to motivate his audience to take refuge in this assembly and thereby achieve fearlessness. How is taking refuge in the protection of bodhisattvas meant to bring about a transition from fear to fearlessness? Why does Sāntideva recommend taking refuge rather than some other remedy, such as mindfulness ${ }^{5}$ or doing good deeds since the object of fear in his verses is karmic suffering, karmic suffering is caused by wrongdoing (7.II), good deeds produce merit, and Śāntideva himself claims that "merit alone is a defense" (2.42). A possible response is that these verses describe the moment of death, at which point there isn't time to do anything else. But Sāntideva's intended audience for these verses is presumably not at the

\footnotetext{
${ }^{5}$ Later in Chapter 5 Sāntideva does propose mindfulness (smṛti) as an appropriate remedy to fear "since all fears and incomparable sufferings arise from the mind alone" (5.6). The question remains, however, why Sāntideva (also) considers taking refuge to be a relevant remedy.
} 
point of death. Why does he motivate them (us!) to take refuge in the Bodhisattvas? To answer this question, it would help to first examine the nature and function of fear in Buddhist thought. While not aiming to provide an exhaustive and complete analysis of fear, this article will take a first step by clarifying some of these puzzling dimensions of Buddhist views on fear.

\section{The 'Paradox of Fear' in the Nikāya suttas}

Sāntideva's use and remarks about fear in BCA have the following narrative structure:

(I) fear is an endorsed motive for action

(2) taking refuge is an endorsed motivated act, and

(3) fearlessness is the goal state of this motivated act.

This narrative structure generates a puzzle. (3) assumes that fear is a negative state to be removed by the action endorsed in (2). (I) positively endorses fear as motive for (2). Taken together, these claims both positively endorse and negatively eschew fear, which seems to be an evaluative contradiction. They also treat fear as the motive for its own removal, which seems to be self-undermining. Can this combination of views, (I-3), be consistently explained and the paradox thereby resolved?

It might be tempting to localize the puzzle to Sāntideva and BCA. However, Brekke (1999) and Giustarini (2012) provide reasons to think that the same puzzle can be found in the Nikāya Suttas, the Theravāda Abhidhamma commentaries, the Vinaya Pitaka, the Milindapañha, as well as the Mahāyāna sūtras. This suggests not only that the "paradox of fear' is prevalent in the Buddhist tradition but that there might also be a wider body of texts from which to derive an exegetical solution. In what follows I will substantiate this suggestion in the Nikāya suttas, with occasional reference to Buddhagoṣa.

Buddhist remarks about fear occur in a soteriological context. A framing assumption of this context is the Buddha's teaching of the Four Noble Truths. Buddhist philosophers 
debate how best to interpret and elaborate these teachings. Broadly speaking, most agree that the first 'truth' articulates the truth or fact of suffering; the second analyses its causes and conditions; the third affirms that suffering can cease and thereby nibbāna ${ }^{6}$ achieved, and the fourth provides a 'path' or guideline for living the relevant way of life and producing this outcome. This path is known as the Eightfold Path and it prescribes, amongst other things, engaging in mindfulness and other forms of contemplative practice as well as cognitive or philosophical analysis aimed at attaining the 'right view' (MN9, MNio, MN28, MNI4I).

The Nikāyas frequently treat fear (bhaya) as a kind and cause of suffering as well as an impediment to be overcome on the path to nibbāna. This is clearest in relation to the Buddha's recommendation that his disciples (bhikkhus) meditate in solitary forest seclusion. There was much to potentially fear in the "remote jungle thicket resting places in the forest" of ancient India (MN4.2). One might be killed by a wild animal or die from an animal bite or sting; one might die from personal injury or from eating poisonous food; one might be murdered by bandits or die as the result of disease (AN5.77). Many suttas address a concern that these perils may cause fear, dread (bherava), fright (uttāsa), terror (chambhitatta), and 'hair-raising' horror (lomahamsa) to arise in a forest disciple, disrupting their concentration and obstructing the obtaining of wisdom (MN4, MNI28, SNI.I5). The Bhayabheravasutta diagnoses these fears as caused by impure bodily, verbal, or mental acts and states, such as a lack of wisdom, lack of persistence, restlessness, uncertainty, and doubt. "Whatever fears arise," says the Bahüdhatukasutta, "[they] all arise because of the fool, not because of the wise man. The wise man brings no fear." (MNII5.2). Not only is fear said to be caused by impurities of conduct and mind, but fear (at least in the form of chambhitatta) is said to be a mental imperfection (uppakilesa) due to its negative influence on meditative practice (MNi28.27). Since the Buddha does not have these defects, he is said to find solace in solitary

\footnotetext{
${ }^{6}$ All terms cited from the Nikāyas will be in Pāli.
} 
practice (MN4). "When...I understood that... fear is an imperfection of the mind" he tells Anuruddha in the Uppakilesasutta, "I abandoned fear." (MNi28.30).

The Sigaläkasutta also identifies fear as one of four causes of bad action from which one must refrain (DN3I.5). Several texts evaluate actions and their products negatively if motivated by fear. Gifts given from fear, for example, are deemed unworthy (AN8.3I). The monastic community is instructed not to appoint someone as assigner of meals if they are motivated by fear (AN5.272). Those who "never yield" to the motive of fear are said to "grow in goodness and repute like the moon at waxing-time" (DN3I.6). There is also a social dimension to the negative motivational influence of fear. Fear and timidity (särajjam) are frequently discussed in the context of public speaking. The Book of Nines identifies "fear of timidity in assemblies" as one of "five fears" a disciple must transcend (AN9.5.4). ${ }^{7}$ The Brahmajälasutta tells us that fear of uttering a mistake when uncertain ('fearing to lie') can cause a person to be evasive (DNI.2.2I). A Buddha, however, "sees no grounds" on which he could be reproached for speaking falsely and so, even in immense social contexts that include hundreds of assemblies of gods and evil beings, the Buddha "roars his lion's roar" and abides "in safety, fearlessness (abhayappatto), and intrepidity" (MNı2.23)

The Nikāyas also frequently treat fear and fearlessness as synonyms for suffering and its cessation. They metaphorically characterise the Buddhist soteriological path as a journey across an expanse of water, the near side of which is dangerous and fearful and the further shore safe and free from fear (MN22.I3-I4, SN35.238). Some Mahāyāna sūtras also treat fear as a synonym of suffering (see Siks. 4.70, 5.104). Buddhagoșa, goes so far as to redescribe the four noble truths in terms of fear, the origin of fear, the freedom from fear and the means to attain it (Vism. 87.II). ${ }^{8}$ According to the Nikāyas, nibbāna is "inaccessible to

\footnotetext{
${ }^{7}$ The others are fear of [loss of] livelihood, fear of disrepute, fear of death, and fear of a bad destination (AN9.5)

${ }^{8}$ This might be prefigured in the Devatāsamyutta: “The straightway' that path is called, and 'fearless' is its destination. The chariot is called 'unrattling,'. Fitted with wheels of wholesome states." (SNI.46). According to Buddhagoṣa's commentary in Spk, 'the straightway' refers to the Eightfold Path and the destination, nibbāna,
} 
fear" (SN8.8) and those who reach it are "beyond all fear and hate, they have escaped all suffering" (MNi30.30). A Buddha is said to be "altogether fearless" (MN56.29); "restrained without fear, not restrained by fear" (MN47.9). Disciples are thus encouraged to persist in their solitary practice and become a "conqueror of fear and dread" (MN6.8), "transcending fear and dread" (MNII9.8) whenever they arise, without fear and dread conquering them. The aim is to be "freed from fear, liberated in the fearless" (SN6.I3).

In apparent contrast, the Anguttara Nikāya contains extensive lists of "future fears" or "future perils" (anāgatabhayāni) on which forest disciples are positively advised to "dwell heedful, ardent and resolute" (AN5.77). They include the dangers of solitary forest seclusion mentioned earlier (being killed by wild animals etc.) as well as the negative impacts of famine, catastrophes, schisms in the Buddhist monastic community, and various corruptions of the Buddha's teachings and discipline (AN5.77-80). More broadly, disciples are advised to dwell on the perils of birth, old age, illness, and death (AN4.II9); on the perils of fire, of floods, of kings, of bandits (AN4.I20); on the perils of self-reproach, of reproach from others, of punishment, and of bad rebirth (AN4.I2O); and, on the results of criminal misconduct and misconduct of the body, speech or mind (AN2.I). Moreover, a central theme of the Majjima Nikāya involves reflecting on the perils of lust or sensual pleasure ( $k a \bar{m} a$, see MN45, MN66). In general, disciples are advised:

$[Y]$ ou should train yourselves thus: 'We will fear [bhaya] the fault pertaining to the present life; we will fear [bhaya] the fault pertaining to the future life. We will be fearful [bhiro] of faults and see peril [bhaya] in faults. It is in such a way that you should train yourselves. It is to be expected that one who is fearful of faults and sees peril in faults will be freed from all faults. (AN2.I)

is fearless because "there is nothing to fear in that and because there is no fear for one who has attained it" (cited in Bodhi trans. 2005: 376) 
The immediate purpose of dwelling on these objects is to generate a 'keen perception of their danger' (bhayasaññā) (AN4.244). This 'keen perception' of danger is either a cause or kind of fear. Graphic depictions of these perils reinforce the idea that a psychological transition - from reflection to fear - is intended to occur (see AN2.I). Moreover, the same term, bhaya, is used to denote both fear and danger, which suggests that the relation between perceiving danger and fear is not merely causal; to keenly perceive or construe some object as dangerous is to fear it.

Many passages further suggest that, in coming to keenly perceive some object as dangerous and thus fear it, it is expected that a disciple will be motivated towards preventative conduct. This is most often conceived in terms of arousing energy (viriya) or a disturbed sense of urgency (samvega) in contemplative practice (AN5.77). Here is a typical example:

Here, a forest disciple reflects thus: I am now dwelling all alone in the forest. But while I am living here, a snake might bite me, a scorpion might sting me, or a centipede might sting me. Because of that I might die, which would be an obstacle for me. Let me now arouse energy for the attainment of the as-yet-unattained, for the achievement of the as-yet-unachieved, for the realization of the as-yet-unrealized (AN5.77)

Several suttas additionally recommend the practice of 'mindfulness of death' (maranasati). In prominent versions, this involves approaching and meditating on skeletons and corpses in various stages of decay in such "awe-inspiring, horrifying abodes" $\left(\mathrm{MN}_{7}\right)$ as charnel grounds and woodland shrines (MNio, MNII9, SN46.57-6I). These practices are distinctive to Buddhism and are elaborated throughout the tradition. The objective of meditating on such 'hideous and fearsome objects' (Vism. 2.56), according to Buddhagosa, is to arouse a sense of urgency (samvega) in religious exertion. ${ }^{9}$

\footnotetext{
9 Note that while prominent forms of 'mindfulness of death' involve fear-generation, this may not be necessary. There are various "ways of recollecting death" (Vims 8.7-8), which might support contemplative practice in different ways (see Vism. 8). It is also unnecessary that reflection on death should generate fear. The Buddha is
} 
Here, then, emerges the paradox of fear in the broader Buddhist context of the Nikāyas. Fear is both a negative mental state that obstructs solitary practice and a positive state that galvanizes it. Disciples are advised to both arouse fear and vanquish it. How are these views to be reconciled?

\section{Giustarini and Brekke}

According to Giustarini (20I2), the "seemingly contradictory nature of fear" (5I3) can be explained away if we conceive of the positive use of fear, on the one hand, and the goals of counteracting fear and fostering fearlessness, on the other, as "essential steps in the same process" (5II) albeit at different stages. The Buddhist path to liberation, Giustarini argues, proceeds 'against the stream' (pațiloma) and so the individual who walks this path needs to make an effort. Fear elicits this effort by first stimulating the individual to engage in contemplative practice and then deeply permeating their meditations "with a sense of urgency" (522). In this respect, fear is "a wise response to the presence of danger", properly perceived (517). Guistarini claims, however, that even as a wise response to danger, fear involves an element of disturbance; it is "a form of suffering that must be extinguished by the practitioner." (524). He concludes that "this stimulus is meant to become obsolete" for an individual who recognises this fact about fear (529). Fearlessness is the obsolescence of fear.

Giustarini thus offers an instrumental strategy in response to the paradox of fear. He treats fear as instrumental to practice and fearlessness as the redundancy of fear once that practice is complete. While something along these lines sounds right, it only works if you ignore those remarks in the Nikāyas that negatively characterise fear as an obstacle to the contemplative practice of a forest disciple. Giustarini's proposal is thus not a solution to the

recorded as reassuring at least one individual to "not be afraid" of death because his death "will not be a bad one" (SN 5.370-I) if he continues in good conduct. This example suggests that whether death should be feared is agent relative. What this agent-relativity amounts to needs explaining. This article will attempt to provide an explanation. 
paradox of fear, if by solution we mean an explanation that renders consistent the positive and negative evaluations of fear and explains away the puzzle that arises from thinking of fear as motivating acts aimed at removing itself. The Nikāyas can shed some light on this last point, however. As mentioned, they frequently use the same term, bhaya, to denote both the object of fear (danger) and the psychological attitude or response to danger (fear). That Sāntideva also alternates these senses of bhaya is reflected in the competing translation choices for this term by scholars of BCA. ${ }^{\text {Io }}$ While it is puzzling to think of inciting an aversive state to motivate acts aimed at removing itself, there is nothing strange in the idea of inciting an aversive state (fear) to motivate acts aimed at removing or averting its object (something dangerous).

Giustarini proposes that fear performs its motivational function by stimulating a sense of urgency (samvega) in individuals. This is supported by the literature cited in the previous section. Brekke (1999) makes a similar proposal. Both claim that the induction of fear is "a necessary step in the contemplative path" (Giustarini 2012: 517, my italics). This last claim is difficult to defend or refute. On the one hand, there is no textual evidence to support it; the actual or even frequent incitement of fear is insufficient proof of necessity. To disprove this claim, however, would require a counterexample; a case of someone who has attained nibbāna but was not initially motivated by fear. It is hard to find such an example. Gautama Buddha is our textbook case of someone who has achieved nibbāna, and he is said to have been initially motivated by samvega after seeing an old man, a sick man, and a corpse

\footnotetext{
${ }^{10}$ Crosby and Skilton (1998), for instance, translate bhaya as danger in BCA 2.54: "I have transgressed your command. Now at seeing the danger (bhaya), terrified (bhito), I go to you for refuge. Destroy the danger (bhaya), quickly!" (p.I8). Steinkellner \& Peck-Kubaczek (2019) similarly translate bhaya as 'peril'. But compare with Batchelor (1979) and Wallace \& Wallace (1997) who translate it as 'fear': e.g. "Previously I transgressed your advice, but now upon seeing this great fear I go to you for refuge. In doing so may this fear be swiftly cleared away" (Batchelor I979: I8); "After neglecting your counsel, in terror I go to you for refuge now as I face this fear. Swiftly remove my fear!" (Wallace \& Wallace 1997: 27). Lest one object that this difference in translation turns on the fact that Wallace \& Wallace and Batchelor are translating from the Tibetan rather than Sanskrit (as reflected in different verse numbering to Crosby \& Skilton), Wallace \& Wallace use 'danger' and Batchelor uses 'terror' for bhaya in BCA 2.42; e.g. "Protectors, I, negligent and unaware of this danger, have acquired many vices out of attachment to this transient life" (Wallace \& Wallace 1997: 26); "O Protectors! I, so unconcerned, unaware of such terror as this, accumulated a great deal of evil, for the sake of this transient life" (Batchelor 1979: I6-I7)
} 
(see Bc ch.3, Thūp p.I64). While it doesn't follow from this that "fear is absolutely necessary" (Brekke 1999: 459) to stimulate contemplative practice, Buddhists clearly find it useful for this purpose.

Brekke contends that the Buddha and Buddhists incite fear for another purpose; namely, religious conversion. The "weapon of fear", he argues, was "part of the missionary arsenal of Buddhists" (458) and is best treated as a proselytizing strategy. In support, Brekke cites several early Buddhist conversion stories which narrate the Buddha converting various peoples, human and non-human, to Buddhism (MN56, DN2, MvI.I5-20). Brekke is right that fear plays a motivating role in these contexts. Consider the following passage from the Mahāvamssa which describes the Buddha's conversion of yakkhas ${ }^{\mathrm{II}}$ on the island of Lankā:

To this great gathering of that yakkhas went the Blessed One, and there, in the midst of that assembly, hovering in the air over their heads..., he struck terror into their hearts by rain, storm, darkness and so forth. The yakkhas, overwhelmed by fear, besought the fearless Vanquisher to release them from terrors, and the Vanquisher, destroyer of fear, spoke thus to the terrified yakkhas: 'I will banish this your fear and your distress, $\mathrm{O}$ yakkhas, give ye here to me with one accord a place where I may sit down.' The yakkhas thus answered the Blessed One: 'We all, O Lord, give you even the whole of our island. Give us release from our fear. (Mhv I.23-27)

It doesn't follow, of course, that religious conversion is the only purpose for which Buddhists incite fear since, as Brekke acknowledges, it also stimulates the Buddha's disciples in contemplative practice. Brekke's emphasis on religious conversion nevertheless raises the question of whether this is what Sāntideva had in mind when he advises taking refuge in 'the Buddhas and Bodhisattvas'. If so, it is hard to see how converting to Buddhism, by itself, could provide a remedy for fear since it was clearly insufficient for those disciples who 'lost

\footnotetext{
${ }^{\text {II }}$ Yakkhas (yakshas Skt.) are a broad class of woodland spirits or demons that appear in Hindu, Jain and Buddhist texts. See DeCaroli (2004)
} 
their minds' (MN4.2) from fear during solitary forest practice. While I do think some kind of commitment or attitude of faith or trust is implied by Śāntideva's notion of taking refuge (along the lines argued in Finnigan 2019), I also think that it has the potential to mean a lot more. The act or practice of 'taking refuge' has a long history in the Buddhist tradition. All major schools of Buddhism acknowledge three sources of refuge, known collectively as the Triple Gem. They are the Buddha, the Dhamma (or the 'truth' as taught by the Buddha, dharma, Skt.), and the Sangha (or the Buddhist community, samgha, Skt.). According to the Dhajaggasutta, the Triple Gem provides refuge from fear.

"For those who thus recall the Buddha, The Dhamma, and the Sangha, disciples, no fear [bhaya] or trepidation [chambittata] will arise, Nor any grisly terror [lomahamsa]" (SNII.3).

Sāntideva clearly acknowledges these three sources of refuge. "With as many prostrations as there are atoms in all the Buddha fields" he writes "I throw myself down before the Buddhas of all three times, before the Dharma, and before the highest assembly." (BCA 2.24) If we extend Sāntideva's conception of 'taking refuge' to include the Triple Gem, his advice implies a potentially richer and more complex explanation of how taking refuge might function to help individuals 'transcend' fear beyond mere commitment to Buddhism. This explanation will likely be informed by the philosophical dimensions of the Buddha's teachings and supported by the social dimensions of the Buddhist community. Spelling it out will not be straightforward, however, since Buddhists disagree on the details.

An explanatory gap remains in the proposed solutions of Giustarini and Brekke. Central to the paradox of fear is the idea that fear is or can cause a "suitable response to a situation" that stimulates contemplative practice, and sometimes is or causes an "improper reaction" that impedes this same practice (Giustarini 20I2: 523). What explains the difference? Giustarini does not say. According to Brekke "the solution to this puzzle is the fact that fear has very different functions under different circumstances: it is the talents and discipline of the individual that make the difference" (I999: 459). While something along 
these lines seems right, it also needs explanation. The Bhayabheravasutta has told us that fear impedes solitary practice for those with unwholesome mental states. It is reasonable to suppose that it galvanises practice for those with at least some wholesome states. But what are the relevant states and how do they relate to fear? Brekke does not say.

I have a positive proposal, inspired by ideas found in the Nikāya suttas. Before elaborating it, I will first give reasons against an alternative approach. The Nikāyas frequently identify and prescribe 'fear of misconduct' (ottappa) as a positive motive for action. Together with shame (hiri), ottappa is described by the Buddha as one of the "two bright qualities [that] protect the world" (ANI.52) because it motivates restraint from wrongdoing. ${ }^{12}$ The pairing of ottappa (apatrāpya, Skt.) and hiri plays an important role in the moral psychology of later Abhidhamma/Abhidharma Buddhism. If ottappa were the sense of fear at issue in the paradox of fear, it might suggest an easy solution: ottappa is positive and prescribed as a suitable response to situations, whereas bhaya is negative and to be eschewed as an improper reaction. While ottappa is indeed positively conceived as, or as causing, a suitable response to certain situations, ${ }^{13}$ it is not the mental state at issue in the paradox of fear. Buddhagoșa characterises ottappa as an aversive attitude to misconduct due to dread of social reproach (Dhs trsl. I26, Vism. I4.I42). This is not relevant to the fears of solitary forest meditators discussed in the Nikāyas, nor does it exhaust the kind of fear prescribed and used by Sāntideva to motivate his audience to take refuge in the Bodhisattvas. Ottappa might be relevant to some cases but appeal to ottappa does not explain why bhaya (and its close cognates) is a suitable response in some cases but an improper reaction in others. The paradox of fear still stands. Identifying the role of ottappa in later

\footnotetext{
I2 "If these two bright qualities did not protect the world there would not be seen here [any restraint regarding] one's mother, aunts, or the wives of one's teachers and [other] respected people. The world would become promiscuous like goats and sheep, chickens, arid pigs, dogs, and jackals. But because these two bright qualities protect the world, there is seen here [restraint regarding] one's mother, aunts, or the wives of one's teachers and [other] respected people." (ANi.52).

${ }^{13}$ There are divergent views, however, about whether ottappa is best analysed as a kind of fear or as 'shame' or 'a sense of decency' (Ñāṇamoli I964: 472; Lodrö Sangpo 20I2: 5I8)
} 
Abhidhamma/Abhidharma nevertheless suggests that there is a richer moral psychology in Buddhist views about fear than engaged here. ${ }^{14}$ While I will now turn to advance my own solution to the paradox of fear, inspired by the Nikāya suttas, this solution is best understood as a preliminary step in a broader conversation about Buddhist views on the nature and function of fear.

\section{Resolving the Paradox}

According to the Bhayabheravasutta, fear impedes solitary practice for those with unwholesome mental states. It is reasonable to suppose that it may galvanise practice for those with at least some wholesome states. What are the relevant states and how do they relate to fear? Thānissaro Bhikkhu suggests that the relevant mental states are delusion and wisdom (20I6: 24). This has exegetical support. The Bahüdhatukasutta claims that whatever fears arise, they all arise because of the fool, not because of the wise man (MNII5.2). What is the relevant cognitive object about which a disciple is deluded or has insight? The Dhammapada suggests that it is the presence of danger:

"Seeing danger when there is no danger, and not seeing danger when there is danger, because of taking up wrong views, beings go to a bad state of rebirth." (Dhp 317).

Combining these ideas, we can derive the following proposal: fear impedes solitary practice for those who are deluded and thus mistaken about the presence of danger but galvanises it for those who are wise and thus rightly perceive its presence (see danger 'as it actually is', MNII).

On reflection, this proposal might seem wrong. Recall the peril of being killed by a wild animal. Disciples are advised to dwell on this peril, ardently and resolutely, until fear and a sense of urgency motivates them to increase their religious exertions (AN5.77). This is

\footnotetext{
${ }^{14}$ I thank an anonymous reviewer for pressing me to engage this point.
} 
also a peril that causes fear and dread to arise in disciples and robs them of their concentration (MN4.2). The object appears to be the same in these cases, both in general kind (danger) and particular instantiation (being killed by a wild animal). It might thus seem that the difference in response is not explicable in terms of a difference in 'what' is feared (what is 'seen as' dangerous).

A closer reading of the Nikāya suttas sheds some light here. Disciples are not actually advised to dwell on the danger of being killed by wild animals but, rather, on the 'obstacle' that being killed would cause: "Because of that I might die, which would be an obstacle for me." (AN5.77). This is also true for the other potential sources of death. What obstacle could death cause? The answer is clearly meant to be that it would prevent contemplative practice and thus the achievement of nibbāna and escape from cyclic existence. What is so dangerous or fearsome about this? The answer, again, is that if one does not achieve nibbāna in this life, then one may not have an opportunity to do so in the next and so one will face karmic suffering in either the next life or some life thereafter. This includes the possibility of being reborn into one of a vast number of hell realms, each with their own distinctive forms of excruciating suffering (MNı30). The Nikāya suttas thus appear to assume a refined conception of 'danger' and thus of the object of fear. The object of fear is danger, but an object is properly (actually, ultimately, truly) dangerous if causally related to karmic suffering. Call this the refined analysis of fear. Fear is or causes a wise response to a situation rather than an improper reaction, we might say, when the individual properly perceives the presence of danger. To properly perceive the presence of danger, however, is to realise, with a disturbed sense of urgency and aversion, that the object is a cause of karmic suffering.

This refined analysis of fear is exegetically informative. First, it explains why fear of 'future perils' positively motivates the arousal of energy and urgency in contemplative practice rather than some other aversive response to these objects. While there might be many ways to avoid the pain and suffering of, say, being mauled to death by a wild animal, 
the only way to avoid karmic suffering, according to Buddhism, is to follow the Buddha's path to liberation.

Second, it explains why sensual pleasure is included in the list of future perils. Sensual pleasure (kāma) typically connotes sexual pleasure but includes any kind of bodily sensory enjoyment. Is it necessarily dangerous? Many of the other perils involve suffering, harm or death to an individual. A desire for sensual pleasure, by contrast, appears to have both negative and positive consequences depending on the context. The Majjima Nikāyas dwell at great length on its potential negative consequences, with graphic emphasis on interpersonal conflict (MNi3, MN45). Yet it is also easy to think of cases where desire for sensual pleasure has positive outcomes such as pleasure for oneself and another when the desire is consensually satisfied, with the potential to cause further pleasure. As several suttas pointedly insist, however, sensual pleasures are impermanent and for this reason it is believed that their pursuit can and will lead to negative outcomes. We find several causal analyses of the underlying psychology to explain this view. A typical example can be reconstructed as follows: an individual associates sensual pleasure with some object (person, event, situation or thing), which then causes them to crave (tanhhā), cling or be attached (upadāna) to that object. This attachment then conditions the individual to experience suffering in the face of inevitable change or loss of that object, given the fact of impermanence, or frustration in the attempt to achieve or maintain the associated pleasure. Unless the individual cultivates wisdom, virtue, and mindfulness, they will be motivated to act in various unwholesome ways to try to secure the object and associated pleasure, and to avoid the suffering associated with change. Even if these actions achieve their goal in the short or mid-term, they do not do so in the long-term because unwholesome actions 
generate karmic suffering. Sensual pleasure is thus a future peril because it motivates unwholesome actions that cause karmic suffering. ${ }^{15}$

"[O]n the dissolution of the body, after death, [those who indulge in sensual pleasure] reappear in a state of deprivation, in an unhappy destination, in perdition, even in hell. There they feel painful, racking, piercing feelings. They thus say, 'This is the future fear those good recluses and brahmins saw in sensual pleasures." (MN45.3)

Third, the refined analysis of fear helps explain away some apparent inconsistencies in Buddhist attitudes towards death. As we have seen, Sāntideva not only endorses fear of death as appropriate but his verses seem positively aimed at inciting fear of death in his audience. In the Sotapattisamyutta, however, the Buddha explicitly reassures an individual, Mahānāma, to "not be afraid" of death. This might suggest that Sāntideva and the Buddha have inconsistent attitudes towards the appropriateness of fearing death. The inconsistency can be explained away if we contextualise their remarks to different prospects of karmic suffering. Śāntideva, for instance, relates fear of death to the karmic suffering likely to result from past misconduct ("Realizing you are like a captive fish, how right it is for you to be afraid right now? How much more so when you have committed evil action and are faced with the intense agonies of hell? (7.II)). The Buddha, by contrast, reassures Mahānāma not to fear death because, if he continues to engage in Buddhist practice, his "demise [viz. rebirth] will not be a bad one" (SN 5.370-I). The evaluative differences between Sāntideva and the Buddha can thus be rendered consistent if fear of death is assumed to be agentrelative given the refined analysis of fear.

Fourth, the refined analysis of fear might help explain why a Buddha is considered to be fearless. Since a Buddha has achieved nibbāna, he clearly has no need to be motivated

\footnotetext{
${ }^{15}$ Not all forms of pleasure are said to be subject to this analysis. For instance, the Buddha of the Lațkikopamasutta identifies and endorses various forms of pleasure or bliss that stem from contemplative practice (e.g. the bliss of renunciation, the bliss of seclusion, the bliss of peace, the bliss of enlightenment). "I say of this kind of pleasure that it should be pursued, that it should be developed, that it should be cultivated, that it should not be feared" (MN66.2I)
} 
by fear to engage in practices aimed at achieving this goal. Fear, for a Buddha, has "become obsolete" (Giustarini 2012: 529). Giustarini also notes that fear is a subtle form of suffering and thus a "fetter that must be overcome" (529) on the path to liberation. A Buddha, for whom all suffering has ceased, no longer experiences fear. This still needs some explanation. On the refined analysis of fear, the object of fear is danger, and an object is properly dangerous if causally related to karmic suffering. A Buddha has achieved nibbāna, has escaped cyclic existence and is no longer subject to karmic suffering. A Buddha thus faces no danger, properly understood, and has nothing to fear.

This does not yet explain why a Buddha is fearless. Just because a Buddha has nothing to fear, properly speaking, does not necessarily mean that he doesn't experience fear. This is because it is possible to fear things that are not actually or properly dangerous (think of the irrational fears of a child); to fear an object it is sufficient that you perceive (construe) it as being dangerous, whether or not it is dangerous in fact. To account for a Buddha's lack of fear, an explanation is needed of how the fact that a Buddha is in no danger bears on his (or her) subjective construal of not being in danger. The refined analysis of fear suggests an explanatory route, however.

Consider the Bhayabheravasutta, which recounts the Buddha's efforts to conquer fear on the night of his enlightenment. It begins with the Buddha's admission that, before his enlightenment, he thought that solitary forest meditation was hard to endure because fear and dread would arise to impede contemplative practice (MN4.3). He reflects further and attributes the arising of fear and dread to impurities of conduct and mind (MN4.4-I9). He goes onto claim that he finds great solace in dwelling in the forest because he "sees in himself" the possession of wisdom (MN4.19) and purity of conduct (MN4.4-7). To test this idea, the Buddha proceeds to meditate in an "awe-inspiring, horrifying abode" (MN4.20) and recounts experiencing "fear and dread coming upon [him]" when the wind rustled the leaves or birds snapped twigs (MN4.20). He claims to have been able to "subdue" (MN4.22) 
this fear and terror each time it arose until his body and mind were sufficiently tranquil, untroubled, concentrated and unified to allow him to enter and abide in the various meditation stages towards enlightenment.

The Bhayabheravasutta does not explain how the Buddha's awareness of possessing these wholesome qualities ('seeing them in himself') enabled him to subdue fear. The refined analysis of fear can help us make sense of it. Several suttas refer to awareness of possessing wisdom as relevant to social anxiety. The Buddha of the Mahāsinhanādasutta claims, for instance, that it is because he "sees no ground" (MNI2.23) on which anyone could reproach him for being wrong in his understanding and teaching of the Dhamma that he "abide[s] in safety, fearlessness, and intrepidity" (MNI2.30) and "roars his lions roar in the assemblies" (MNI2.27). The Buddha's awareness of possessing wisdom (and thus his awareness that his understanding and teaching of the Dhamma is correct) explains why he sees no ground or reason on which he could be reproached by others for speaking falsely. It makes sense to think that if one is completely assured of one's views, all things considered, one will not be afraid to proclaim them publicly. This does not yet explain how being aware that one possesses wisdom or has purity of conduct might help one subdue fear in solitary practice. It nevertheless does provide grounds for an analogous argument. The Buddha, in his wisdom, understands that the object of fear, properly conceived, is danger related to karmic suffering. He also understands that pure conduct does not cause karmic suffering and he is aware that his conduct is pure. So, just as on account of being aware of possessing wisdom, the Buddha 'sees no ground' to fear the reproach of others and is thus fearless in social contexts, just so on account of being aware that he possesses wisdom (and the understanding about karma that it entails) and is also aware that his conduct is pure, the Buddha 'sees no ground' to fear karmic suffering and is thus fearless in his conduct.

No doubt this is a protracted and incomplete account of a Buddha's fearlessness. It does not explain, for instance, the role of the various meditative attainments (jhänas) in 
achieving the cessation of karmic suffering and thus the achievement of nibbāna. Nor does it explain the function of the other elements of the Buddhist Eightfold Path for achieving fearlessness or how the aspects of the Buddha's Dhamma relating to karma and cyclic existence, about which he is said to possess wisdom, relate to other aspects of his Dhamma, such as the doctrine of no-self (anatta). The above analysis might also introduce some new puzzles. For instance, the meditative attainments are thought to destroy the taints or residual causes of karmic suffering generated by past conduct (MN4.32). In contrast, the above account implies that awareness of purity of conduct is a means to solitary practice (it enables the Buddha to subdue fear in order to engage in solitary practice) rather than being achieved by means of solitary practice. These considerations do not undermine the central point, however; that danger in relation to karmic suffering is the proper object of fear with respect to which a Buddha is fearless.

Here then is a more detailed exegetical solution to the paradox of fear that applies both to the early Buddhist teachings and its commentaries as well as to the writings of Śāntideva. Like Giustarini, I think that the positive incitement of fear is intended to be instrumental to practice and becomes redundant once the goals of this practice are achieved..$^{16}$ Rather than motivating acts aimed at removing itself, which seems paradoxical, its purpose is to motivate practices aimed at removing danger, which is the object of fear. This does not yet explain why and how fear positively galvanises the practice of some disciples (and thus is or causes a wise response to a situation) while negatively impeding that of others (and thus is or causes an improper reaction). The refined analysis of fear helps here. While two distinct disciples engaged in solitary forest practice may experience fear in response to the same kind of situation (e.g. hearing woodland sounds and anticipating the attack of a wild animal), fear motivates different aversive responses due to different

\footnotetext{
${ }^{16}$ I also grant Brekke's claim that fear is sometimes used for the purpose of religious conversion, but I think that this is less philosophically interesting than the function of fear to galvanise Buddhist practice.
} 
construals of the relevant danger. Fear impedes contemplative practice for the disciple who (only) sees danger in the suffering caused by being mauled to death by that animal, but it galvanises the practice of the disciple who possesses sufficient wisdom to realise that (I) death would obstruct their ability to avoid karmic suffering, (2) karmic suffering is the true danger to be averted, and (3) practice is the wisest aversive response to karmic suffering. Wisdom and the lack thereof inform these different construals of the relevant danger. Since wisdom is considered to be a wholesome quality and its lack (delusion) an unwholesome quality, it follows that these agent-relative qualities are the determining factor for whether fear impedes or galvanises contemplative practice.

Finally, with respect to resolving the paradox of fear, the above account can help explain why a Buddha is 'altogether fearless' (MN56.29) and not galvanised in contemplative practice by fear. Fear galvanises the response of a disciple who possesses sufficient wisdom to realise that (I) death would obstruct their ability to avoid karmic suffering, (2) karmic suffering is the true danger to be averted, and (3) practice is the wisest aversive response to karmic suffering. A Buddha, in their wisdom, not only realises (I-3) but they are also aware that their conduct is pure, that they have purified all karmic taints, and have thereby escaped the karmic cycle of rebirth. A Buddha is thus fearless because they realise that they are in no danger, properly understood, and thus have nothing to fear. 


\author{
ABBREVIATIONS \\ AN Añuttara Nikāya of The Buddha in Bodhi (trans.) (20I2) \\ Bc Buddhacarita of Aśvaghoșa in Willeman (trans.) (2009) \\ BCA Bodhicaryāvatāra of Śāntideva in Crosby \& Skilton (trans.) (1998) \\ Dhp. Dhammapada of The Buddha in Norman (trans.) (1997) \\ Dhs trsl. Atthasālinī of Buddhagoșa in Rhys Davids (trans.) (1958) \\ DN Dìgha Nikâya of The Buddha in Walshe (trans.) (1995) \\ MN Majjima Nikāya of The Buddha in Ñānamoli \& Bodhi (trans.) (1995) \\ Mv Mahāvagga of the Vinaya Pițaka in I.B.Horner (trans.) (2007) \\ Mhv Mahāvamsa of Mahānāma in Geiger (trans.) (1908) \\ Miln. Milindapañha in Horner (trans.) (1964) \\ P. Pāli \\ Siks. Ś Sikṣā-samuccaya of Śāntideva in Goodman (trans.) (2016) \\ SN Samyutta Nikāya of The Buddha in Bodhi (trans.) (2005) \\ Skt. $\quad$ Sanskrit \\ Spk Sāratthappakāsin of Buddhagoṣa cited in Bodhi (trans.) (2005) \\ Thūp. Thüpavamssa of Vācissara in Jayawickrama (trans.) (197I) \\ Vism Visuddhimagga of Buddhaghosa in Nānamamoli (trans.) (1964)
}

\title{
REFERENCES
}

Batchelor, S. (trans.) (1979) A Guide to the Bodhisattva's Way of Life by Acarya Sanntideva, Library of Tibetan Works \& Archives, Dharamsala

Bodhi Bhikkhu (1995) Introduction, in B.Ñāṇamoli \& B.Bodhi (trans.), The Middle Length Discourses of the Buddha: A Translation of the Majjima Nikaya, Wisdom Publications

Bodhi, Bhikkhu (trans.) (2005), The Connected Discourses of the Buddha: A Translation of the Samyutta Nikaya, Wisdom Publications

Bodhi, Bhikkhu (trans.) (20I2), The Numerical of the Buddha: A Translation of the Anguttara Nikaya, Wisdom Publications

Braarvig, J. (2009) The Buddhist Hell: An Early Instance of the Idea? Numen, 56 (2/3), pp.254-28I

Buddhaghosa, (1964). The Path of Purification: Visuddhimagga, Bhikkhu Ñānamoli (trans.) Colombo, Buddhist Publication Society

Crosby, K. \& Skilton, A. (trans.) (1998) The Bodhicaryāvatāra, Oxford University Press

DeCaroli, R. (2004) Haunting the Buddha: Indian Popular Religions and the Formation of Buddhism, Oxford University Press

Finnigan, B. (2019) Śāntideva and the moral psychology of fear, in J.Gold \& D.Duckworth (eds.) Readings of Śāntideva's Guide to Bodhisattva Practice (Bodhicaryāvatāra), Columbia University Press, pp.22I-234

Geiger, W. (trans.) (1908) The Mahāvamsa, The Pali Text Society

Giustarini, G. (2012). The Role of Fear (Bhaya) in the Nikāyas and in the Abhidhamma, Journal of Indian Philosophy, 40:5II-53I

Goodman, C. (trans.) (2016) The Training Anthology of Santideva: A Translation of the Siksasamuccaya, Oxford University Press

Harvey, P. (200o) An Introduction to Buddhist Ethics, Cambridge University Press

Horner, I.B. (trans.) (2007) The Book of Discipline: Vinaya-Pitaka, The Pali Text Society Jayawickrama, N.A. (trans.) (1971) The Chronicle of the Thupa and the Thupavamsa, Being a Translation and Edition of Vacissaratthera's Thupavamsa, London, Luzac

Horner, I.B. (trans.) (1964) Milinda's Questions: Milindapanha, Wisdom Publications

Lödro Sangpo, Gelong (English trans. of LV Poussin) (2012) Abhidharmakośa-Bhāṣya of Vasubandhu, Delhi: Motilal Banarsidass

Monier-Williams, M. (1992) A Sanskrit-English Dictionary, Oxford University Press 
Ñānamoli, Bhikkhu \& Bodhi, Bhikkhu (trans.) (1995), The Middle Length Discourses of the Buddha: A Translation of the Majjima Nikaya, Wisdom Publications

Norman, K.R. (trans.) (1997) The word of the doctrine (Dhammapada), Oxford: The Pali Text Society

Rhys Davids, C.A.F. (revised and edited) (1958) The expositor (Atthasalini): Buddhaghosa's Commentary on the Dhammasangani, the first book of the Abhidhamma Pitaka, London: The Pali Text Society

Steinkellner, E. \& Peck-Kubaczek (trans.) (2019) Śāntideva's Bodhicaryāvatāra: A translation, in P.Schmidt-Leukel (ed.) Buddha Mind - Christ Mind. A Christian Commentary on the Bodhicaryāvatāra, Christian Commentaries on Non-Christian Sacred Texts 9, Leuven - Paris Bristol, CT: Peeters

Ṭhānissaro Bhikkhu (2016) The Karma of Questions: Essays on the Buddhist Path, Creative Commons Attribution - Non-Commercial, Mettā Forest Monastery

Wallace V.A. \& Wallace B.A. (trans.) (1997) A Guide to the Bodhisattva Way of Life by Śāntideva, Snow Lion Publications

Walshe, M. (trans.) (1995), The Long Discourses of the Buddha: A Translation of the Digha Nikaya, Wisdom Publications

Whitney, W.D. (2006) The roots, verb-forms and primary derivatives of the Sanskrit language, Delhi: Motilal Barnasidass

Willemen, C. (trans.) (2009), Buddhacarita: In Praise of Buddha's Acts, Berkeley, Numata Center for Buddhist Translation and Research 